\title{
Zero Tilled-Paddy Straw Mulched Potato (Solanum tuberosum) Cultivation in the Coastal Saline Soils Reduce Soil Salinity, Increase Yield and Profitability ${ }^{+}$
}

\author{
Sukanta Kumar Sarangi 1,*, Buddheswar Maji 1, Parbodh Chander Sharma 2, Saheb Digar 1, \\ Kshirendra Kumar Mahanta ${ }^{1}$, Dhiman Burman ${ }^{1}$, Uttam Kumar Mandal ${ }^{1}$, Subhasis Mandal ${ }^{1}$ \\ and Mohammed Mainuddin ${ }^{3}$ \\ 1 Central Soil Salinity Research Institute, Regional Reseach Station, Canning Town, South 24 Parganas -743 \\ 329, India; b.maji57@gmail.com (B.M.); sahebdigar1988@gmail.com (S.D.); mahantakk@gmail.com (K.K.M.); \\ burman.d@gmail.com (D.B.); uttam_icar@yahoo.com (U.K.M.); subhasis2006@gmail.com (S.M.) \\ 2 Central Soil Salinity Research Institute, Karnal-132 001, India; pcsharmaknl@gmail.com \\ 3 CSIRO Land and Water, Black Mountain Laboratories, Canberra ACT-2601, GPO Box 1700, Australia; \\ Mohammed.Mainuddin@csiro.au \\ * Correspondence: sksarangicanning@gmail.com \\ + Presented at the third International Tropical Agriculture Conference (TROPAG 2019), Brisbane, Australia, \\ 11-13 November 2019.
}

Published: 5 April 2020

\begin{abstract}
Rice is the predominant crop during wet season (July-December) and majority of land remain fallow during dry season (January-June) in the coastal saline region of West Bengal, India. Sustainable cropping system intensification in this salt affected region needs improved package of practices which conserve soil moisture, facilitate early crop establishment, ensures profitability and has positive effect on soil health. To achieve these objectives in a rice-based cropping system, we evaluated seven treatments for potato crop during the dry season viz. T1: ridge sowing (control), T2: Zero tillage (ZT) sowing with $9 \mathrm{t} \mathrm{ha}^{-1}$ paddy straw mulching (PSM), T3: T2 + foliar spray of nutrients, T4: ZT sowing with $12 \mathrm{t} \mathrm{ha}^{-1} \mathrm{PSM}, \mathrm{T}$ : T4 + foliar spray of nutrients, T6: ZT sowing with $15 \mathrm{t} \mathrm{ha}^{-1}$ PSM, T7: T6 + foliar spray of nutrients in randomized block design with five replications. This study was conducted during 2016-2019 in the Gosaba island of the Indian Sundarbans. Cost of cultivation of potato reduced by about $27 \%$ due to ZT sowing (₹ $81,287 \mathrm{ha}^{-1}$ ) compared to ridge sowing $\left(₹ 1,11,260 \mathrm{ha}^{-1}\right)$. Tuber yield, net return and irrigation water productivity was significantly increased in T5, T6 and T7 over other treatments. There was reduction in soil salinity (ECe reduced from 5 to $3 \mathrm{dS} \mathrm{m}^{-1}$ ), bulk density (from 1.49 to $1.44 \mathrm{Mg} \mathrm{m}^{-3}$ ), irrigation water use (less $20 \mathrm{~cm}$ ), conservation of soil moisture (4-8\%), and increase in organic carbon (0.39 to $0.44 \%$ ) due to ZT sowing with PSM. Rice-ZT potato-green gram cropping system was the most profitable one with highest net return (₹ 1,71,752 ha-1), however, the benefit-cost ratio was highest (2.33) with Rice-ZT potato cropping system.
\end{abstract}

Keywords: bulk density; irrigation water; mulching; organic carbon; soil moisture; soil salinity; tillage 
Funding: This research was funded by the Australian Centre for International Agricultural Research (ACIAR) under the project "Cropping system intensification in the salt-affected coastal zone of Bangladesh and West Bengal, India (LWR/2014/073)".

(C) 2020 by the authors. Licensee MDPI, Basel, Switzerland. This article is an open access article distributed under the terms and conditions of the Creative Commons Attribution (CC BY) license (http://creativecommons.org/licenses/by/4.0/). 